\title{
A SZÍNHÁZPEDAGÓGIA ÉS A FEJLESZTŐPEDAGÓGIA KAPCSOLÓDÁSI PONTJAI
}

\section{Szerzők:}

Bancsi Zoltán

(Magyarország)

Mező Katalin (Ph.D.)

Debreceni Egyetem

(Magyarország)

Első szerző e-mail címe:

bancsi.zoltan@gmail.com

\section{Lektorok:}

H. Tóth István (Dr. CSc.)

Univerzita Karlova

(Csehország)

Mező Ferenc (Ph.D.)

Eszterházy Károly Egyetem

(Magyarország)

és két további anonim lektor...

\section{Absztrakt}

Jelen publikáció a színházpedagógia megjelenési lehetőségeit taglalja a fejlesztőpedagógiában. A tanulmány célja: 1) felszínre hozni azokat az élménypedagógai elemeket, amelyek lehetővé teszik e két, látszólag elkülönülő (színházpedagógia és fejlesztőpedagógia) terület összekapcsolását; 2) bemutatni egy olyan pilot kutatás eredményeit, melyben középiskolás fiatalok $(\mathrm{N}=100)$ körében történt a színházpedagógiai előadások fejlesztési céllal történő felhasználási lehetőségeinek elemzése. A vizsgálati eredmények alátámasztották, hogy a színházpedagógiai előadás (mint élményadó közeg) alkalmas eszköz lehet fejlesztőpedagógiai célzatú felhasználásra is.

Kulcsszavak: színházpedagógia, fejlesztôpedagógia, élménypedagógia

Diszciplína: pedagógia

\section{Abstract:}

THE CONNECTION BETWEEN THEATER PEDAGOGY AND

DEVELOPMENTAL PED AGOGY

This publication discusses the possibilities of the emergence of theater pedagogy in developmental pedagogy. The aim of the study is: 1) to bring to the surface the elements of experiential pedagogy that allow the connection of these two seemingly 
separate (theater pedagogical-developmental pedagogical) fields; 2) to present the results of a pilot research in which we examined the possibilities of using theater pedagogical performances for development purposes in the case of high school students $(\mathrm{N}=100)$. The results of the study confirmed that theater pedagogical performance (as an experience-giving medium) can also be a suitable tool for developmental pedagogical use.

Keywords: theater pedagogy, developmental pedagogy, experiential pedagogy

Discipline: pedagogy

Bancsi Zoltán és Mező Katalin (2020). A színházpedagógia és a fejlesztőpedagógia kapcsolódási pontjai. OxIPO - interdiszciplináris tudományos folyóirat, 2020/4, 23-39. doi: 10.35405/OXIPO.2020.4.23

A színházi nevelés tekintetében egyfajta pedagógiai struktúraváltás figyelhetô meg. Egyre több színház próbál nyitni a fiatalabb nemzedék, a diákok felé azáltal, hogy olyan pedagógiai célzatú előadásokat készítenek, melyek során a nézőből tevékeny résztvevő lesz, s így az előadás közben megélt élmények és megfogalmazott gondolatok közvetve vagy közvetett módon járulnak hozzá az egyén személyes fejlődéshez. Ebből következően a színházi nevelés a fejlesztőpedagógiai egyik tudatosan alkalmazott részterülete is lehet.

E tanulmányban a színházpedagógia és fejlesztőpedagógia kapcsolódási pontjainak bemutatására kerül sor - rámutatva arra, hogy a színházi nevelés során alkalmazott módszerek miként épülhetnek be a fejlesztő foglalkozások menetébe.

\section{A színház mint értéket adó, generációkat formáló közösség}

A színház prózai, zenés, táncos színpadi művek előadásával foglalkozó előadómúvészeti szervezet, mely működési típusai szerint lehet: bábszínház, befogadó színház, produkciós színház, független színház, szabadtéri színház, nemzetiségi színház (2008. évi XCIX. törvény az előadóművészeti szervezetek támogatásáról és sajátos foglalkoztatási szabályairól 7.§). A színházba járás egyike azon szabadidős lehetőségeknek, amelyek érdeklődést válthatnak ki felnőttből, gyermekből egyaránt. A színház sajátossága, hogy egy-egy színházi előadás alkalmával az ember újra egy kicsit gyermek lehet, hiszen gondolati síkon (olykor tevőlegesen) újra játékos tevékenységet végezhet. 
A gyermek, amikor játszik, akkor önfeledt. Ezt az élményt adja vissza az interaktív színház, hiszen játszani enged. Amikor gyermekként játszik az ember, akkor tulajdonképen már a felnőtt életre is készül, mivel megtanulja feldolgozni, megnevezni az őt ért különböző élethelyzeteket, s egy sor olyan készségeket próbál elsajátítani, amelyek a későbbiekben akár a személyes, akár a társas kapcsolataiban a segítségére lehetnek. Ez is vonzóvá teheti a színházba járást az emberek számára, mely afelé sarkallhatja a látogatókat, hogy a szabadidő-eltöltésnek ezt a formáját válasszák.

Ahhoz, hogy megértsük a színház igazi varázsát, érdemes közelebbről is megnézni mindazt, ami a színpadon és a közönség soraiban végbemegy egy-egy előadás alkalmával. A színdarabok megtekintésekor fontos azt hangsúlyozni, hogy egy olyan mûvészeti ágról van szó, ahol az átváltozás jegyében élő ember jeleníti meg az élő embert, és ezzel egyedülálló élményt, találkozást biztosít mind a színészeknek, mind a közönség tagjainak is.

A színdarabok sokszínűsége azt is biztosíthatja, hogy a jelenetek elját-szása, megtekintése során az egyén önmagára is ismerhessen. A színház, és benne a színészek által eljátszott darabok tükröt tartanak a nézők elé, akik felis-merhetik ezekben önmagukat, rácso-dálkozhatnak arra, hogy hogyan is élik a mindennapi életüket.
A színházi előadások, az ott bemutatásra kerülő jelenetek abban is segíthetik az embert, hogy kilépjen önmagából, a világról alkotott elképzeléseiből, és olyan új, számára talán eddig ismeretlen életformákkal, élethelyzetekkel, gondolatokkal találkozzon, amelyekre az eddigi életében nem figyelt fel. Az előadások nemcsak önmaga megértését segítik, hanem közelebb vihetik a másik emberhez, ezáltal fejlesztve az egyénben a másik ember iránti megértés, elfogadás képességét.

Az interaktív színházi előadás aktivitást vár el a nézőtől, egy olyan nyitott, befogadó magatartást, amelyben a néző valóban jelen van, gondolatban együtt mozog a színészekkel, tulajdonképen része az egész előadásnak (vö.: Deme és Sz. Deme, 2010).

Fontos mozzanat az is, hogy a különbözô előadásokon való részvétel nagyban segítheti és fejlesztheti az ember képességeit, tudását. A gyermekek, a fiatalok számára egy-egy előadás alkalmat nyújthat arra, hogy fejlesszék a különböző tantárgyi tudásukat, megtanuljanak holista módon gondolkodni (ami az OxIPO modell alapú tanulásnak is egyik célkitűzése, lásd. Mező, 2011), képet kapjanak az emberi természetről és a különböző, már bennük lévő, vagy a későbbiekben kibontakozó érzésekről is. A színházi nyelvezet segítségével pedig megtanulják mindezeket kifejezni, elmondani önmaguknak, önmagukról. 


\section{A színházpedagógia története}

A mai kor talán egyik legnagyobb problémája az, hogy nagyon sokat beszél az emberről mint homo sapiensről, a gondolkodó emberről, valamint az alkotó emberről, a homo faber-ról, aki tervez, alkot, elméleteket, gyárt, és ezeket igazolja, de ritkábban esik szó az emberi mivoltunkat jellemző tulajdonságunkról: a játékoságról (a homo ludens, a játékos, játszó ember vonatkozásában lásd: Huizinga, 1944). A játék nem csak a gyerekek életének a része, ami a felnőttek komoly és kemény világképébe már nem fér bele. A játék révén a felnőtt ember is felszabadulhat, önmaga lehet. Nyíri Tamás (1972, 260.) szerint „aki játszik, kilép az időből és másik időbe lép át.”

A magyar színházi életre jellemző volt, hogy két típusú előadást szerveztek: egyrészt kisgyermekek vehettek részt különböző bábszínházi előadásokon, másrészt a felnőtt generáció számára állítottak elő felnőtt előadásokat, de a köztes életkorú, „fiatal” korosztály igazából nem lett megszólítva (vö.: Prezsmer, 2014). Majd megjelentek a diákbérletes előadások, melyek alkalmával humoros, zenés darabokat adtak eló, azzal a céllal, hogy becsábítsák a színházba a fiatalokat és kineveljék közülük majd a közönség utánpótlását. De előfordulhatott, hogy az ellenkező hatást váltotta ki e törekvés, mivel egyrészt a fiatalok nem a saját nyelvükön lettek megszólítva; másrészt az adott, amúgy klasszikusnak számító darabok nem az ő életükhöz kapcsolódó problémákat és megoldási kísérleteiket tárták fel, hanem elbeszéltek a fejük fölött. Így a fiatalok között lehettek olyanok, akik kiábrándultak és elfordultak a színháztól.

Újszerű színfoltként jelent meg a színházi palettán a napjainkra jellemző színházpedagógia, amely viszont egy egészen más módszert alkalmaz (megjegyzés: azt is mondhatjuk, hogy azok a színházak, amelyek a színházpedagógiát bátran merik vállalni, igazi felfrissülést hoznak). A színházpedagógiát alkalmazó színházak eddig bezárt ablakokat nyitogatnak, amelyek mögött az érdeklődő fiatalok azt várják, hogy valaki végre észrevegye és megszólítsa őket. Nagyon fontos szemléletváltás történt ezekben a színházakban: rájöttek, hogy ha találkozni szeretnének a fiatalokkal, akkor szakítani kell az eddigi jól megszokott, szinte már kővé dermedt szokásokkal, és nem a színháznak kell várnia, hogy a fiatalok végre meginduljanak felé, hanem a színháznak kell megtenni az első, de legfontosabb lépést, azaz meg kell jelenni a fiatalok hétköznapi életében, az iskolákban, valamint a szabadidejükben. A szemléletváltáshoz szorosan hozzátartozik az is, hogy a színházaknak el kell fogadniuk, hogy ne a leendő közönségük oszlopos tagjait lássák a most még tizenévesekben, hanem olyan fiatal nézőket, akik aktuálisan nyitottak az élet problémáira. Őket most kell megszólítani a nekik készült darabok segítségével, válaszolva a bennük lévô számtalan kérdésre és a közöttük lévő 
problémákra. Ezek a darabok csak akkor lesznek igazán hitelesek, ha a fiatalok azt érzik, itt végre valóban velük foglalkoznak, és róluk van szó, az ő életükről. Lényeges szempont az is, hogy az adott darab lehetőleg segítse a fiatalokat a problémamegoldásban, mert a mai fiatal generációnál kevés olyan közösség van, ahol megbeszélhetnék a bennük lévő kérdéseket, problémákat. Egy-egy színházpedagógiai előadás nem konkrét válaszokat akar adni, nem a fiatalok helyett szeretné megoldani a problémát, inkább arra törekszik, hogy utat mutasson, olyan pozitív példát, amely követendő lehet a fiatalok számára.

\section{A színházpedagógia programja}

A színházpedagógia keretében az előadásokon a színészek minden egyes alkalommal arra törekednek, hogy kimozdítsák a résztvevőket a jelenlegi világukból, és a darabban felmerülő problémákra közösen keressenek megoldásokat. Bár Magyarországon is megjelentek a felnőttek számára készített színházpedagógia előadások, de az igazán érintettek a köznevelésben részt vevő diákok. Az előadások lehetőséget biztosítanak arra, hogy az adott életkorban felmerülő kérdések, problémák (például a családi életben, az iskolai, osztályközösségben, vagy pedig a gyermek egyéni életében megjelenő helyzetek) felszínre kerüljenek, és a közös továbbgondolás által segítse elő a megoldást.

A program során olyan előre már elkészített előadást, vagy jelenetsort láthatnak a résztvevők, ahol nagy szerepet kap az önkifejezés is. Az alkotók feladata lesz, hogy egy adott korosztály számára a színházpedagógia előadásokból kiválaszszák azt a darabot, ami valóban megérinti és továbbgondolásra serkenti a résztvevőket. De nem elég csupán az adott korosztály, illetve a megfelelő színdarab kiválasztása, az alkotóknak abban is nagy felelősségük van, hogy megtalálják azt a kapcsolódási pontot, amelyen keresztül a program és a részvevők egymásra találhatnak. A színházpedagógiai programok során az érintettek számára lehetőség nyilik, hogy ők maguk formálják, vezessék a darab folytatását, véleményt nyilváníthatnak, ezáltal is segítve önmaguk és a társaik számára az adott darab legfontosabb üzenetének feldolgozását, megértését. Ezen színházpedagógia előadásokon különböző módszereket alkalmazhatnak az alkotók. A drámapedagógia mellett helyet kaphat a tánc, illetve a mozgásszínház, valamint a bábjátékok, és a darabban található jelenetek újrajátszása is segithet abban, hogy a darab valóban az alkotók és a résztvevők közös alkotása legyen.

Az előadásokhoz általában szorosan szokott kapcsolódni színházpedagógiai foglalkozás is. Ezek a projektek jó lehetőséget kínálnak arra, hogy az előadáson éppen részt vevő csoport reakcióihoz 
igazítva, különböző egyéb módszerek bevonásával közösen gondolkodjanak a látott darab további üzenetéről.

\section{A színházpedagógia programelemei}

A mai oktatási rendszerben megjelentek azok az eszmék, melyek célul tűzték ki, hogy a diákok körében egyre inkább népszerűvé tegye a színházba járást, illetve a színdarabok megtekintését (lásd: színházbarát iskola program). De nagyon sokszor tapasztalható, hogy ha a diák el is megy a színházba, arra törekszik, hogy ő csak néző legyen, egy valaki a sok közül, és az előadás után, letudva a kötelező programot, tovább is lép a saját világán belül. A színházpedagógia azonban mindent megtesz annak érdekében, hogy az ott lévők ne csak nézők legyenek, hanem résztvevők is. Egy-egy színházi nevelési foglalkozáson nemcsak erkölcsi, morális kérdések jelennek meg, hanem olyan mikro- és makrotársadalmi problémák, amelyek szorosan érintik a diákokat a hétköznapi, családi életékükben, vagy az iskolai élet terén. A darabban nem csak egyszerűen játszanak a színészek, a nézők pedig jelenlétükkel megtisztelik az előadást, hanem valamennyien tevékeny résztvevői is a darabnak, megfogalmazhatják és elmondhatják gondolataikat, együtt játszhatnak az alkotókkal. „A színházi nevelési programok sokszor szélsőséges példákat mutatnak, hogy ezzel még a legkényelmesebb nézőt is állásfoglalásra kényszerítsék. A nézőnek meg kell kérdezze magától, ebben a helyzetben vajon én is ugyanezt tenném. A cél, hogy a néző résztvevő belehelyezkedjen az adott helyzetbe és meghatározza ahhoz füződô viszonnyá" (Takács, 2008, 108.).

A színházpedagógia előadások igazi célja, hogy a résztvevőkben elinduljon egy igazi változás, megtörténjen a valódi bevonódás. A bevonódásnak a mélysége határozza meg a darab további életét. $\mathrm{Ha}$ sikerült megszólítani a diákokat, akkor igazi, mély dolgok is előkerülhetnek, ha viszont ezt nem sikerül megvalósítani, akkor csak felszínes lesz az egész előadás hatása. Ehhez szorosan hozzátartozik az is, hogy a diák ne csak néző legyen, hanem résztvevő-néző, aki tevékenyen bekapcsolódik az alkotói munkába (Hajós-Lipták, 2010).

A következő fontos elem a nyitás. A színházpedagógiai előadások jelenetekből, illetve ezekhez szorosan hozzákapcsolódó, a látott jelenetek feldolgozását segítő interaktív részekből állnak. A nyitás ezen interaktív szakasz első része lesz, ahol az alkotók tevékeny részvételre bíztatják a résztvevőket.

A nyitást követően az interaktiv szakasz. következik mint új elem. Ebben a részben olyan cselekvési elemeket találunk, amelyek lehetőséget biztosítanak a többirányú kommunikációra. Az interaktív szakasz egy hosszú folyamat, mely segíti a látott darab megértését, valamint a felszínre kerülő különböző érzések, legyen akár pozitív vagy negatív érzés feldolgozását. „A művészetpszichológia egyik 
alapvetése, hogy a műalkotás érzelmileg mozgósíthat, kellemetlen élményeket is felidézhet bennünk, melyek azonban kockázat nélkül, biztonságos körülmények között élhetőek át” (Fleck, 2007, 22.).

Az utolsó szakasz a színházpedagógia program elemeit tekintve az utánkövetésutógondozás. Ami a hazai helyzetet illetően (bár igen fontos területről van szó) még mindig gyerekcipőben jár. Az utánkövetés legfontosabb feladata, hogy megismerje és felmérje a látott színházpedagógiai előadás hatásait.

Ennek két formája van: 1) az előadást követően az alkotókkal együtt közösen beszélik meg a darab kapcsán felmerült kérdéseket, illetve mindazt, ami megfogalmazódott a diákokban. 2) Az osztályteremben történik, az alkotók személyesen, vagy valamilyen kérdőív, illetve egyéb más eszközök segítségével arra törekszenek, hogy visszajelzést kapjanak a diákoktól és a pedagógusoktól is. Az előadás után az utókövetésben nagy szerepe lesz az osztályfönöknek, illetve mindazoknak a pedagógusoknak, akik a tanulókkal együtt, de nem résztvevőként, hanem megfigyelőként vettek részt az előadásban. A foglalkozást követően felmerülhetnek olyan kérdések, érzések, gondolatok, amelyekről beszélni kell. Az alkotók nem tudnak folyamatosan jelen lenni egy-egy közösség életében, de a pedagógus igen. Rajtuk is múlik, hogy az utánkövetés mennyire lesz hatásos, illetve milyen változásokat eredményez akár az egyén, akár a közösség életében. „Nem tudjuk, meddig tart a színházi nevelési előadás. Nem tudjuk mérni hosszú távú hatásait. A pedagógusok segítségével, témát és élményt adva a kezükbe erősíthetjük a mindannyiunk számára fontos kérdések csengését.” (Hajós-Lipták, 2010, 3.).

\section{A színházpedagógia}

\section{és a fejlesztőpedagógia kapcsolata}

A fejlesztőpedagógia a normál intelligencia övezetbe tartozó, de egyes részképességek terén segítségre szoruló és/vagy beilleszkedési, tanulási, magatartási nehézséggel küzdő gyermekek és fiatalok megsegítésére szolgáló, tudatosan szervezett pedagógiai tevékenység (Mező, 2017).

E tanulók között gyakran találunk olyat, akik az életkorukhoz viszonyítottan jelentősen alulteljesítenek, társas kapcsolati problémákkal küzdenek, tanulási és/vagy magatartásszabályozási hiányosságaik vannak, a közösségbe való beilleszkedésük, személyiségfejlődésük nehezített vagy sajátos tendenciákat mutatnak (2011. évi CXC. törvény a nemzeti köznevelésről). Noha a fejlesztőpedagógia célcsoportjába a 3-10 éves korosztályba tartozó gyermekek tartoznak, ugyanakkor a későbbi életkorokban (akár serdülőkorban) is szükség lehet fejlesztőpedagógiai célú beavatkozásokra. Ez megtörténhet színházpedagógia keretében is.

A fejlesztőpedagógia és a színházpedagógia összekapcsolása látszólag nehézséget jelenthet, de ha jobban megvizsgáljuk 
a két területet, sok hasonlóságot, illetve kapcsolódási pontot figyelhetünk meg. Kapcsolódási pontok: mind a két terület...

...egymást segítheti, illetve kölcsönösen kiegészítheti a legfontosabb célt szem elôtt tartva, ami nem más, mint maga a gyermek segítése (Örkény Színház, Szakmai beszámoló, 2020).

...arra törekszik, hogy a diákokat megszólítsa, ezt követően pedig az adott területen alkalmazandó módszerek segítségével a diákokkal közösen a lehető legtöbb eredményt elérjék. E két terület összekötő személye a pedagógus (ezen belül az osztályfőnök, különösen, aki fejlesztőpedagógusi végzettséggel is rendelkezik), akinek van arra lehetősége, hogy mindennap tevékenyen részt vegyen a diákok életében. Az ő megfigyelése, illetve jelzései révén e két terület szakemberei szoros együttműködést tudnának kialakítani.

...célja a komplex fejlesztés. A fejlesztésbe bevonható képességek között szinte valamennyi képesség megjelenhet (például az észlelés, érzékelés, figyelem, emlékezet, gondolkodás, a nyelvi képességek, a motoros képességek stb.). Az önkontrollos hatásvizsgálattal minőségbiztosított fejlesztési sémát figyelembe véve (diagnosztika-fejlesztés-utóvizsgálat, lásd: Mező, 2017), így jelen lehet a monitorozás, a nyomon követés és az ellenőrzés is egyegy diák fejlesztendő területe kapcsán. A fejlesztő órát követően a színházpedagógiai előadás teret és alkalmat biztosítana arra, hogy egy-egy feladat gyakorlása megtörténjen és rögzítésre kerüljön. Illetve a színházpedagógiai előadásokon való részvétel a felszínre hozhat a diákok életéből olyan fejlesztendő területeket, amelyekre a fejlesztőpedagógia megfelelő segítséget tud nyújtani.

...célja a személyiségfejlesztés, különös tekintettel a magatartásszabályozási, társas kapcsolati problémák közösségi megélése terén.

...akkor mûködik jól, ha élményadó jellegű. Annak ellenére, hogy a színházat sokan outdoor (intézményen kívüli) élménypedagógiának tekintik, a színházpedagógia ékes példája az indoor jellegú élménypedagógia alkalmazási lehetőségének (bővebben Mező, 2015).

\section{A színházpedagógia útjai és lehetőségei az iskolai fejlesztés során}

A drámapedagógia, illetve a színházpedagógia és az oktatás közötti kapcsolat nem újkeletű dolog. A mai oktatási rendszer egyre inkább kezdi felfedezni a színházpedagógiában lévő lehetőségeket, bár nagyon sok helyen még a hagyományos oktatási elveket és elemeket alkalmazzák, illetve alapvetően hiányzik az iskola életéből a pedagógiai, és a módszertani változtatás, megújulás. Ezeken a helyeken a dráma, illetve színházpedagógiának az oktatásban betöltött szerepét félreértelmezik vagy egyáltalán nem is alkalmazzák. „A tanári, tanítói hivatás általában nagyon 
alacsony presztízsű, ráadásul a színház- és drámapedagógusokat gyakran inkább szórakoztató szakembereknek tekintik, mintsem ,igazi” tanároknak; így elismertségük, akár a pedagógus szakmában, akár a kultúra területén vagy a szélesebb társadalomban, igen alacsony mértékü." (DICE, 2010).

A színházpedagógiai foglalkozások nem arra törekszenek, hogy a részvevő diákok színészi készségeit elmélyítsék, illetve a színészi pálya felé tereljék őket (bár ezen alkalmak erre is alkalmasak lennének), de a legfontosabb cél, hogy a diákok önismerete gazdagodjon, a világnézetük fokozatosan bővüljön.

A színházpedagógia sohasem személytelen alapigazságokat fogalmaz meg, hanem olyan tapasztalatot próbál átadni a résztvevő diákoknak, amelyek mögött ott van a személy, illetve jelen van az érzelmi intelligencia is. A cél, hogy ezek a fiatalok a mindennapi életben is tetteikért felelős, együttérző, gondolkodó emberek legyenek (Marunák, 1991).

A színházi nevelés teret és lehetőséget biztosít a résztvevők számára arra is, hogy különböző szerepek kipróbálásával, egyegy élethelyzet több oldalról való megközelítésével, illetve a közös gondolkodással fejleszthessék az alapvető kulcsképességeiket. „Valamennyi kulcskompetenciát egyformán fontosnak kell tekinteni, hiszen mindegyik hozzájárulhat a sikeres élethez a tudásalapú társadalomban. Sok kompetencia részben fedi egymást és egymásba fonódik: az egyik területhez elengedhetetlenül szükséges elemek támogatják a másik terület kompetenciáit. Az alapkészségek megléte a nyelv, az írás, olvasás, számolás, valamint az információs és kommunikációs technológiák (IKT) terén elengedhetetlen alapja a tanulásnak, míg a tanulás elsajátítása támogatást nyújt minden tanulási tevékenység számára. Számos olyan téma van, amely a referenciakeret egészében alkalmazásra kerül: a kritikus gondolkodás, a kreativitás, a kezdeményezés, a problémamegoldás, a kockázatértékelés, a döntéshozatal és az érzelmek konstruktív kezelése szerepet játszik mind a nyolc kulcskompetencia esetében.” (Az Európai Parlament és a Tanács ajánlása, 2006, 14.). Tekintsük át a kulcskompetenciákat a színházpedagógia aspektusából!

Anyanyelvi kommunikáció. A színházpedagógiai előadások nagyban segíthetik a résztvevők anyanyelvi fejlődését. Gavin Bolton angol drámapedagógus többször felhívta a szakemberek figyelmét arra, hogy a nyelv és a mozgás mint kifejezőeszköz, kulcsfontosságú szerepet kell hogy betöltsön a résztvevők életében. Véleménye szerint a dráma maga a nyelv, és ennek szemléltetésére egy igen érdekes képet használ. Bolton ezt a kapcsolatot úgy ábrázolja és nevezi, hogy „pókháló kép”, ahol a dráma jelenti magát a hálót, a nyelv pedig azon fonalakat, amelyek magát a pókhálót alkotják és összetartják. A kettő nem tudna egymás nélkül létezni (Bolton, 1993). Az előadások során számtalanszor előfordul, hogy a résztve- 
vők lesznek azok, akik a szereplők helyébe lépnek, megszólaltatják őket, vagy épp az előadás során használt tárgyat, illetve eszközt személyesítenek meg a hang, illetve a szavak, a beszéd segítségével. Ezen mozzanatok nagyon jó alkalmak arra, hogy a diákok hangképzését, illetve beszédjük prozódiai sajátosságait, a hangerôt, hangsúlyt, beszédtempót is gyakorolják.

A tanulás tanulása. A színházi nevelési előadások abban is segíthetik a tanulókat, hogy az iskolai oktató-nevelő munka során hallott és kapott ismereteket, illetve információkat hogyan kell helyesen rendszerezni, feldolgozni és elsajátítani. A tanulás tanulása azt is jelentheti, hogy az előadások során megfogalmazódott akár egyéni, akár közösségi tapasztalat, gondolat felidézhető, beépíthető lehet az iskolában, a családban, illetve a későbbi élethelyzetekben is előhívható, felhasználható (bővebben lásd OxIPO modell, Mező, 2011).

Személyközi, interkulturális és szociális kompetenciák. A foglalkozások mindig csoportban, közösségben történnek. Így arra is van lehetőség, hogy a résztvevők megismerjék, elsajátítsák és alkalmazzák azokat a viselkedési normákat, amelyek lehetővé teszik számukra azt, hogy tevékeny módon tudjanak részt venni a közösség életében, illetve későbbiekben a társadalom aktív tagjai legyenek. Megtanulhatják a közösségi élet különböző szabályait, valamint azt is, hogyan, milyen módon lehet egy-egy felmerülő konfliktust helyesen megoldani.

Vállalkozói kompetencia. Talán az egyik legnehezebben fejleszthető terület. Az iskola, de még a család is mint közösségi élet színtere nagyon kevés alkalmat ad arra, hogy a gyermekek, fiatalok szabadon kibontakozzanak, kreatívak legyenek. A színházpedagógiai előadások során számtalan lehetőség áll a résztvevő diákok előtt, legyen szó egyéni vagy közös feladatmegoldásról, jelenetek felállításáról, hogy felfedezzék és kibontakoztathassák a vállalkozókedvüket, kreativitásukat.

Esztétikai, müvészeti tudatosság és kifejezőkeészség. A programok révén művészeti nevelés is történik. A résztvevők nemcsak az adott darab üzenetével találkozhatnak, hanem a színész, illetve drámapedagógus játékán a mûvészet világába is betekintést nyerhetnek. A színészek által kapcsolhatják az adott témához a különböző órákon elhangzott ismereteket, így rendszerezve, felhasználva a rendelkezésükre álló tudást (DICE, 2010).

Miért van szükség a drámára, illetve a színházpedagógia előadásokra a nevelésben és a fejlesztésben? Ha a fentebb említett kompetenciákat nézzük, azt láthatjuk, hogy a színházi nevelési programok hatással lehetnek a fiatalokra nemcsak a tudás megszerzése és alkalmazása kapcsán, hanem a személyiségfejlődést tekintve is. „A kreatív dráma kísérlet a tudás személyessé tételére. Kulcsfogalmai: szerep és azonosulás. A tanulók szerepbe lépnek: elképzelik, hogy mit tennének egy 
adott szerepben, illetve helyzetben. Valójában a feladattól függ, hogy menynyire adhatják magukat, csak a helyzet van-e meghatározva vagy a karakter bizonyos vonásai is. De az utóbbi esetben is interakcióba lép a tanuló saját személyisége és a karakter, amellyel átmenetileg azonosulnia kell, és jó esetben bekövetkezik a helyzetben rejlő probléma belsőleg átélt megértése" (Knausz, 2001, 82.). Mindezeket látva azt gondoljuk, hogy a színházpedagógiának helye van az oktatás életében, mert az előadásokra nemcsak úgy kell tekinteni, mint az oktatás módszertani eszközeire, hanem olyan programokra, amelyek azon túl, hogy elősegítik egyes készségek és képességek kibontakozását, illetve fejlődését, élmény alapú oktató-nevelő tevékenységet is végeznek.

\section{A színházpedagógia hatása:}

\section{fiatalok körében végzett kutatás}

A következőkben egy, a színházpedagógiai előadás hatásainak megismerésére irányuló vizsgálat bemutatására kerül sor, melyet az előadáson résztvevő fiatalok és az őket kísérő és tanító osztályfőnökök körében végeztünk el. Jelen kutatás egy nagyobb ívű élménypedagógiai kutatás része, melyben a hazai iskolákban fellelhető élménypedagógiai elemek alkalmazására fog fény derülni (Mező, 2020). A vizsgálatban arra kerestük a választ, hogy a diákok részt vesznek-e színházpedagógiai előadásokon, illetve hogy jelent-e olyan élményt a számukra, melyek alapján ajánlanák a társaiknak a színházpedagógiai programban való részvételt. A pedagógusok véleményei esetében arra voltunk kíváncsiak, hogy ők felfedeztek-e valamilyen változást, fejlődést a színházi nevelési programot követően az osztályuk életében, és ha igen, akkor milyen jellegü és erejü volt ez a változás.

\section{Hipotézisek}

1. Feltételeztük, hogy a megkérdezett tanulók színházba járáshoz való viszonyulása pozitív.

2. Feltételeztük, hogy a színházpedagógiai előadáson való részvételt a résztvevők olyan élményként élik meg, melyek alapján ajánlanák a tevékenységet a társaiknak.

\section{Módszer}

A vizsgálat során saját összeállítású tanulói kérdőívek felvételére került sor, amelyek igen-nem választ kértek a következő kérdésekre: szeretsz színházba járni, szoktál színházba járni, ajánlanád-e másoknak a színházpedagógiai programokban való részvételt. Illetve, arra is kíváncsiak voltunk, hogy milyen gyakorisággal járnak színházba a fiatalok. A vizsgálati eredmények értelmezésekor leíró statisztikai elemzést, illetve khinégyzet próbát végeztünk.

\section{Minta}

A kutatás során olyan osztályokat szólítottunk meg, akik a 2019/2020. tan- 
évben vettek részt színházpedagógiai előadáson, mert fontosnak tartottuk, hogy a kérdőív kitöltésénél a diákok könnyen felidézhessék a különböző élményeiket, az őket ért hatásokat. A kiválasztott megyeszékhelyen (Debrecenben) lévő középiskola nyitott beiskolázású intézmény, ebből következően a településen kívülrôl is érkeznek tanulók más városokból, falvakból. Az iskola koedukált jellegéből adódóan lehetőségünk nyílt lányok és fiúk megszólítására (1. ábra.)

1. ábra. Nemi elosqlás a vizsgált ( $n=100$ fó) középiskolások körében. Forrás: Szerzők.

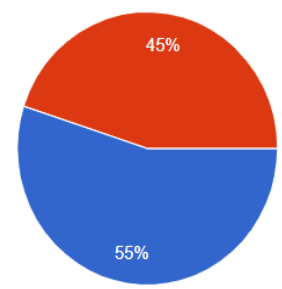

A tanulói kérdőívet három osztályból 100 fő (13-16 éves tanuló) töltötte ki, 45 fő lány és 55 fő fiú (a khi-négyzet próba szerint nincs szignifikáns különbség a nemek létszáma tekintetében, v.ö.: 1. ábra). A pedagógusokkal végzett interjúban 3 fő osztályfőnök kísérő tanár vett részt.

\section{Eredmények}

A tanulói kérdőívben található kérdések egy része a kitöltésben résztvevő diákok színházkedvelési és színházlátogatási szokására irányult.

A válaszadók nagy része, $74 \%$ igennel felelt arra a kérdésre, hogy szeret-e színházba járni, s mindössze 26\%-uk jelezte, hogy nem szeret színházba járni (khinégyzet $=23,040, \mathrm{df}=1, \mathrm{p} \leq 0,01-$ lásd: 2.a ábra). Ugyanakkor 66\%-uk mondta azt, hogy szokott is színházba járni, és 34\%-uk nem szokott színházba járni (khinégyzet $=10,240, \mathrm{df}=1, \mathrm{p}>0,01$ - lásd: 2.b. ábra).

A színházkedvelés tekintetében pozitív választ adók és a színházba járás között megfigyelhető különbség (74 fő szeret színházba járni, de csak 66 fő jár színházba) véleményünk szerint abból adódik, hogy a kérdőív kitöltésében résztvevők különböző területi nagyságú és lélekszámú településeken laknak.

A válaszadók nagy része, több mint 70\%-a, Debrecen városában, vagy a hozzá tartozó agglomerációs területen él, így sokkal több lehetőség adódik számukra, hogy a város által felkínált különböző színházi programokon részt vegyenek, mivel a városban több színház is működik (Csokonai Színház, Nagyerdei Szabadtéri Színpad, Vojtina Bábszínház, Debreceni Egyetemi Színház).

A kutatásban részt vevők 26\%-a nem szeret, illetve 34\% százaléka nem jár színházba. Feltételezésink szerint ez összefügghet azzal, hogy a válaszadók 30\% olyan kistelepüléseken lakik, ahol nagyon kevés alkalom és lehetőség adódik arra, hogy az élő színházzal találkozzanak. 
2a. ábra. A válaszadók önbevallása arról, bogy szeretnek-e színháąba járni. Forrás: szerzook.

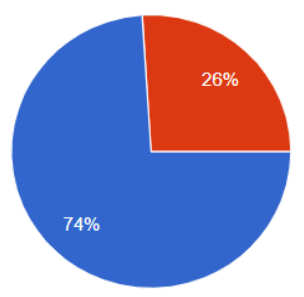

A vizsgálatban arra is kitértünk, hogy a diákok milyen gyakorisággal vesznek részt színházi előadásokon. Az eredmények alapján megállapítható, hogy a válaszadók $31 \%$-a csak évente vesz rész előadáson, 28\%-a félévente és negyedévente minimum egyszer; a kérdőívet kitöltőknek csak a 13\%-a válaszolta azt, hogy havonta minimum egy előadáson vesz részt (khinégyzet $=7,920, \mathrm{df}=3, \mathrm{p}>0,05$ - lásd: 3. ábra). 2b. ábra. A válaszadók önbevallása arról, hogy szoktak-e szinháaba járni. Forrás:

szerzők.

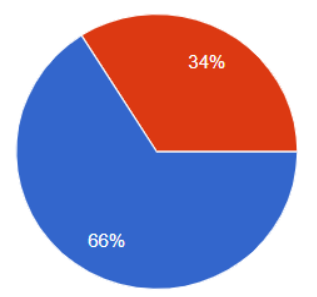

A következőkben kifejezetten a résztvevők színházpedagógiához való viszonyát, valamint az ott megtapasztalt élményeket igyekeztünk vizsgálni. A színházpedagógia terjedését tekintve figyelemre méltó eredmény az, hogy a válaszadók 98\%-a már hallott az iskolákban megvalósuló iskolai, osztálytermi színházról (khi-négyzet $=92,160, \mathrm{df}=1, \mathrm{p}<0,01$ ), és a diákok 74\%-a vagy a jelenlegi, vagy az előző iskolájában már részt vett ilyen programon (khi-négyzet $=23,040$, df $=1$, $\mathrm{p}<0,01)$.

3. ábra. A szinhbázba járás gyakorisága. Forrás: Szerzóke.

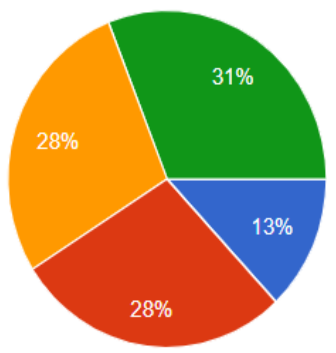

havonta minimum egyszer

negyedévente minimum egyszer

félévente minimum egyszer

évente 
A megtekintett előadások sokszínűségét jól jellemzi, hogy az érintett osztályok mindegyike különböző programon vett részt attól függően, hogy az adott osztályban milyen megoldásra váró probléma volt jelen. A résztvevők által az adott előadással kapcsolatban megfogalmazott értékelések szinte minden esetben pozitív hangvételűek voltak. A diákok nemcsak egy jó hangulatú, élményt adó interaktív osztályprogram lehetőségét látták az előadásokban, hanem olyan alkalmat is, amely során lehetőségük adódik arra, hogy egy problémát közösen körbejárjanak, és a lehetséges megoldási javaslatokat közösen fel is tárják.

Mindez a kutatásban részt vevő osztályfőnökökkel készült interjúkérdések során is igazolást nyert, mivel mind a három osztályfőnök hangsúlyozta, hogy a mai gyerekek a közös beszélgetések során nagyon kevésszer tudnak igazán megnyílni, és hangot adni a véleményüknek, de az előadások interaktív jellege révén erre is meg volt a lehetőségük.

A színházpedagógiai előadások egyik lényeges tulajdonsága, hogy a diákok résztvevőként bekapcsolódhatnak az előadásba. A válaszadók megfogalmazásiból kiderül, hogy nagy élmény volt számukra az, hogy nemcsak nézőként, hanem tevékeny szereplőként vehettek részt a darabban. Volt olyan, aki csak bizonyos jelenetek megformálásában vállalt szerepet, de olyan is volt, akit teljesen magával ragadt az előadás, így tevékenyen kivette a részét a darab megvalósításából. Az inter- júk során az osztályfőnökök is kiemelték, hogy külön örültek annak, hogy az osztály „hangadói mellett” azok is megszólaltak és megfogalmazták gondolataikat, akik inkább csendes emberként vannak jelen a közösség életében. A kérdőív kitöltése során a diákokkal együtt arra is kerestük a választ, hogy volt-e, és ha igen, mi volt az a gondolat, ami az előadás kapcsán felmerült bennük. A résztvevők között voltak olyanok, akik megfogalmazták, hogy a darab hatására felfedezték és önmagában megfogalmazták a társaik számára is megszívlelendő, a mindennapi életbe beépíthető gondolatokat. Az érintett pedagógusok is kiemelték, hogy a program utóélete igen színes és változatos volt. Az osztályfőnök vezetésével a diákok különböző formában és módon, de beszélgettek a látott előadásról, a bennük megszületett érzésekről, gondolatokról, ezáltal is segítve önmaguk, valamint a közösség fejlődését is.

Arra is kíváncsiak voltunk, hogy a megkérdezett diákok részt vennének-e újabb színházpedagógiai programon, másrészt ajánlanák-e társaik, barátaik körében ezt az élményt. Mindkét kérdésre a válaszok 88\%-a igenlő volt, ezért egy ábrán szemléltetjük (

4. ábra; khi-négyzet $=57,760, \mathrm{df}=1, \mathrm{p}$ $>0,01)$.

$\mathrm{Az}$ eredmény elemzése során kiderült, hogy a válaszadók 88\%-a nemcsak újra részt venne, hanem ajánlaná is ezt a programot: megfogalmazásuk szerint, egyrészt, 
mert élményt ad és elgondolkodtató üzenetet hordoz magában, másrészt az interaktív előadási mód és a közös jelenetalkotások révén több lehetőség adódik az együttműködési képesség fejlesztésére is.

4. ábra. A színházpedagógiai elöadás népszerüsége a diákok körében. Forrás: szerzoole.

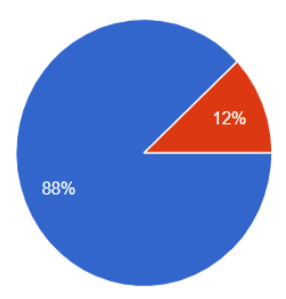

A jövőbeli kutatás fókuszálhatna a pedagógusok véleményére azzal kapcsolatban, hogy milyen fejlesztő hatása van a színházpedagógiai előadásoknak. A jelenlegi vizsgálatban a három fővel végzett osztályfőnöki interjúban a pedagógusok kiemelték és hangsúlyozták a program jelentőségét. Azt nyilatkozták, hogy ezek az előadások jó lehetőséget kínálnak a diákoknak arra, hogy a jelenetek előkészítése, valamit azok eljátszásakor fellépő viták alatt egymás véleményét tiszteletben tartva fejlesszék a beszédkészségüket, kommunikációjukat. Valamint azáltal, hogy a diákok az adott előadás során különböző mozgásokat végezhetnek, a mozgáskoordinációjuk is alakulhat, fejlődhet. Ugyanakkor az interjúkban megjelenő ala- csony mintaszám alapján ezen állításokat nem lehet igazolni, így a későbbiekben célszerű erre fókuszáló vizsgálatokat végezni.

\section{Konklúzió}

Az első hipotézisben feltételeztük, hogy a megkérdezett tanulók színházba járáshoz való viszonyulása pozitív. Az eredmények ezt a feltételezést alátámasztották, mivel a megkérdezett fiatalok 74\%-a nyilatkozott úgy, hogy szeret színházba járni és emellett $66 \%$ válaszolt úgy, hogy szokott is színházba járni. Ez azért meglepő, mert a KSH (2011) adatbázisa alapján a színházlátogatások aránya még a fövárosban is csak 55\% volt, s a többi városban 43\%-ra tehető (KSH, 2011,5.)

A következőkben azt feltételeztük, hogy a színházpedagógiai előadáson való részvételt a résztvevők olyan élményként élik meg, melyek alapján ajánlanák a tevékenységet a társaiknak. Erre egyértelmú igazolást jelent az az eredmény, hogy a 100 tanuló közül 88 fő szívesen venne részt újabb színházpedagógiai programon, másrészt ajánlaná társai, barátai körében ezt az élményt. Korosztályi sajátosság a nyitott, szabad véleményalkotás, így valószínűleg az ettől eltérő, negatív véleményt is bátran vállalnák. Ugyanakkor csak 12 fiatalnak volt ezzel ellentétes véleménye a színházpedagógiai programmal kapcsolatban (bár arra nem kaptunk magyarázatott, 
hogy miért nem szeretnének újra bekapcsolódni ilyen jellegű programba).

A pedagógusokkal végzett beszélgetésekből tükröződött, hogy a válaszolók nagyon fontosnak tartják a színházpedagógiai előadások fejlesztő hatását, mert úgy érzik, fejlődik a tanulók beszédkészsége, vitakészsége, kommunikációja, szociális kapcsolatrendszere, problémamegoldó készsége, valamint az empatikus készsége is. Ezen visszajelzések alapján valószínűsíthető a színházpedagógia fejlesztőpedagógiai célzattal történő alkalmazásának létjogosultsága is, különösen a magatartási, beilleszkedési nehézséggel küzdő tanulók esetében. A résztvevő diákok, valamint a program során jelen lévő pedagógusok is felfedezték és megtapasztalták a program közösségi, interaktív, élménypedagógiai részét, amely hozzásegítheti őket ahhoz, hogy az életükben megjelenő problémákat a színházpedagógiai helyzetben kivetítsék, és ez a projekció hozzájárulhasson a személyes nehézségek megoldásához. A kutatásunk során keletkezett eredmények nagyon hasonlóak ahhoz, amit Marunák (1991), valamint Bolton (1993) megfogalmazott. Mind a két kutató úgy tárja elénk a színházpedagógia fontosságát, hogy kiemeli annak az egyéni fejlesztési területen betöltött szerepét.

\section{Összegzés}

Jelen tanulmány a színházpedagógia és a fejlesztőpedagógia között fellelhető kap- csolódási pontok feltárásáról szólt. Megvilágításra került, hogy a két terület szimbiózisa elképzelhető és kivitelezhető a fiatalok fejlesztése terén. A pedagógiában keresni kell az olyan újszerű eszközöket és fejlesztési módokat, mint például a színházpedagógia.

A középiskoláskorú fiatalok fejlesztőpedagógiai ellátása gyakran azért aggályos, mert nehezükre esik elfogadni, hogy még ebben a korban is külön fejlesztésre szorulnak. A színházpedagógia esetében megvalósuló varázslat során a fiatalokban talán nem is azonnal tudatosul, hogy problémakezelésre, a nehézségek megfogalmazására és kimondására, esetlegesen megoldására is sor kerülhet az előadás alatt/után. Ugyanakkor a színházpedagógia által nyújtott megtapasztaláson alapuló pozitív vagy negatív élmény hosszútávon rögzül, így erre építve tudatos fejlesztőpedagógiai programok, egyéni fejlesztési tervek kidolgozására is sor kerülhet.

\section{Irodalom}

2008. évi XCIX. törvény az előadóművészeti szervezetek támogatásáról és sajátos foglalkoztatási szabályairól. Net: https://net.jogtar.hu/ jogszabaly?docid=A0800099.TV Letöltés: 2020.11.10.

Az Európai Parlament és a Tanács ajánlása (2006. december 18. ) az egész életen át tartó tanuláshoz szükséges kulcskompetenciákról. Net: 
https://eur-lex.europa.eu/legalcontent/HU/TXT/?uri=CELEX $\% 3$ A32006H0962 Letöltés: 2020.11.10.

Bolton, G. (1993). A tanítási dráma elmélete. Marczibányi Téri Mûvelődési Központ, Budapest.

Deme J. és Sz. Deme L. (2010). Ha a nézọ" is résztvevoóvé válna. Kisérletek a szinhbáz és a köaönség viszonyának újragondolására. L'Harmattan, Budapest.

DICE - a kocka el van vetve (2010). Kutatási eredmények és ajánlások a tanitási szinház és dráma alkalmazásával kapcsolatban, DICE Konzorcium.

Fleck E. (2007). Agresszió művészeti, pszichiátriai és terápiás megközelítésben. Tanitó, 45 (7.). 22-25.

Hajós Zs. és Lipták I. (2010). A színházi nevelésről hat tételben. Drámapedagógiai Magazin Különszám 2. 3-5.

Huizinga, J. (1944). Homo ludens, kisérlet a kultura játék-elemeinek meghatározására. Ford. Máthé K., Budapest, Athenaeum.

Knausz I. (2001). A tanítás mestersége. Net: $\quad$ http://mek.oszk.hu/01800 /01817/01817.pdf, Letöltés: 2020. március 23.
KSH (2011). Színpadi szórakoztatás. Központi statisztikai hivatal. Net: https://www.ksh.hu/docs/hun/xftp/ idoszaki/pdf/szinhaz11.pdf. Letöltve: 2020.11.10.

Marunák F. (1991). Mi is az a drámapedagógia? Drámapedagógiai Magaẓin 1. szám, 3-4.

Mező F. (2011). Tanulás: diagnosztika és fejlesztés az. IPOO modell alapján. $\mathrm{K}+\mathrm{F}$ Stúdió Kft., Debrecen.

Mező F. (2017). Fejlesztöpedagógia. K+F Stúdió Kft., Debrecen.

Mező K. (2015). Kreativitás és élménypedagógia. K+F Stúdió Kft., Debrecen.

Nyíri T. (1972). Antropológiai vázlatok. Szent István Társulat, Budapest.

Prezsmer B. (2014). Színházpedagógia, drámapedagógia. Játéktér, 2014. téli szám.

Örkény Színház (2020). Szakmai Bemutatkozás. Net: https://iram. orkenyszinhaz.hu/szakmai-bemu tatkozas-iram/ .Letöltés: 2020. március 19.

Takács G. (2008). A magyarországi gyerek- és ifjúsági kultúra egyik intézménye: a Káva Kulturális Múhely. Iskolakultúra, 7. 8. szám: 108-119. 